\title{
Tuhan, Manusia, dan Alam: Analisis Kitab Primbon Atassadhur Adammakna
}

\author{
Samidi \\ Balai Litbang Agama Semarang
}

\begin{abstract}
This article is the result of the library research on the divining manual book, usually known as Kitab Primbon Atassadhur Adammakna written by Pangeran Tjakraningrat. Kitab Primbon commonly consists of mystical lessons, magical practices, and oracles or fortune-telling. However, Kitab Primbon Atassadhur Adammakna precisely explains the Javanese philosophy which adopts the Islamic lessons, especially tasawuf. The lessons of God, human, and universe are appropriately described with the Javanese tradition and culture. Keeping the harmony of the relationship between human and universe is an obligation, since it also means keeping the harmony with the God, as the Creator of the universe.
\end{abstract}

Keywords: God, Human, Universe, and Kitab Primbon

\begin{abstract}
Abstrak
Tulisan ini merupakan hasil kajian pustaka (library research) terhadap Kitab Primbon Atassadhur Adammakna karya Pangeran Tjakraningrat. Kitab primbon pada umumnya mengandung ajaran mistik, klenik, dan ramalan atau nujum. Namun kitab Primbon Atassadhur Adammakna ini justru menguraikan ajaran filsafat Jawa yang mengadopsi ajaran Islam, khususnya tasawuf. Konsep manusia, Tuhan, dan alam Ajaran tentang Tuhan, manusia, dan alam dijabarkan sesuai dengan adat dan budaya Jawa. Menjaga keselarasan hubungan antara manusia dengan alam adalah kewajiban, karena sama artinya menjaga keharmonisan dengan Tuhan, sebagai Sang Pencipta Semesta.
\end{abstract}

Kata kunci:Tuhan, Manusia, Alam, Kitab Primbon 


\section{Pendahuluan}

Tuhan, manusia, dan alam merupakan pembahasan filsafat klasik yang tidak pernah ada habisnya. Negeri-negeri seperti Mesir, India, Cina, Jepang, Iran, Babilonia, Yunani, dianggap sebagai rujukan dalam mempelajari konsep tersebut. Para filosof kuno sampai filosof modern sudah banyak yang mengupas tentang hal ini. Manusia merupakan bagian dari alam semesta (kosmos) yang telah diciptakan oleh Allah SWT., dan sebagai abdiNya. Manusia diberikan kuasa oleh Tuhan untuk memanfaatkan, mengolah, dan menjaga potensi alam semesta yang telah diciptakan-Nya (khalifatullah). Dengan alam pula manusia berproses dan memperoleh pengetahuan dari Tuhan. Oleh karena itu membahas hubungan antara manusia, alam, dan Allah SWT sebagai pencipta tidak dapat dipisahkan.

Pembahasan tentang manusia, Tuhan, dan alam semesta juga terdapat di dalam berbagai literatur atau kepustakaan Islam Kejawen. Kepustakaan Islam Kejawen merupakan salah satu kepustakaan Jawa yang memuat perpaduan antara tradisi Jawa dengan unsur-unsur ajaran Agama Islam (Simuh 1988, 2). Kepustakaan ini menggunakan aksara dan bahasa Jawa, sedangkan isinya bernuansa mistik dan sedikit yang mengungkap permasalahan syariat Islam. Kepustakaan ini termasuk kategori kepustakaan Islam, karena banyak mengungkap ajaran-ajaran Islam, meskipun ada sebagian yang tidak menghargai aspek syariatnya. Oleh sebab itu, kepustakaan ini dimasukkan dalam kategori karya Sastra Jawa (Djamil 1999, 25).

Karya sastra di Jawa, secara sosio-budaya dibedakan menjadi dua (2), yaitu: sastra Jawa Pesisiran dan sastra Jawa Pedalaman (Djamil 1999, 25-26). Sastra Jawa Pesisiran memiliki hubungan erat dengan proses perkembangan kehidupan keagamaan, karena kehidupan sehari-hari masyarakat dianggap tidak dapat lepas dari kerangka agama. Karya-karya yang muncul memperlihatkan warna agama lebih dominan, bahkan cenderung mempertahankan legalitas agama dari masuknya elemen-elemen yang mengandung unsur-unsur yang menyesatkan. Sementara Sastra Pedalaman, yang semula bercorak Hindu sentris menjadi berbau ke-Islaman; perpaduan antara ajaran Islam dengan elemen-elemen mistik Hindu. Karya-karya pujangga keraton yang mengupas Islam melibatkan elemen-elemen mistik yang berlawanan dengan aspirasi kaum pesisiran. Ajarannya lebih dekat dengan Hindu daripada Islam.

Kepustakaan Islam Kejawen yang membahas tentang manusia, Tuhan, dan alam diantaranya adalah Kitab Primbon Atassadhur Adammakna karya Pangeran Tjakraningrat. Kanjeng Pangeran Harya (KPH) Tjakraningrat lahir pada tahun 1829, dan meninggal pada tahun 1916. Jenazahnya dimakamkan di pemakaman Kenanga Mulya Desa Plered, sekitar petilasan Keraton Kerto Mataram (Noeradya 1983, 9). 
Pangeran Tjakraningrat atau Patih Danuredjo VI ini merupakan sosok yang produktif, karena melahirkan banyak karya sastra. Kitab Primbon Bektijamal Adammakna memberikan banyak petunjuk tentang karya-karyanya, antara lain (Noeradya 1983, 8): Kitab Adammakna, Kitab Primbon Betaljemur, Kitab Primbon Lukmanakim Adammakna, Kitab Primbon Atassadhur Adammakna, Kitab Primbon Bektijamal Adammakna Ayah Betaljemur, Kitab Primbon Shadhatsahthir Adammakna, Kitab Primbon Qoamarrulsyamsi Adammakna, Kitab Primbon Naklassanjir Adammakna, Kitab Primbon Quraysin Adammakna, Kitab Primbon Ajimantrawara Yogabrata Yogamantra, Kitab Primbon Kunci Betaljemur, Serat Damarwulan, Serat Anglingdarma, Pakem Ringgit Gedhog, Babad Diponegara, Babad Kebumen, Cakrajaya, Jalasutra, Sruni, Spei, Handayaningrat, Pakem Wayang Kandha Purwa, Babad Segaluh, Babon Jangka Jayabaya, Babad Mataram, Bedahing Padjajaran, Daha Kediri, dan Babad Giri.

Selain karya-karya tersebut, KPH Tjakraningrat juga memiliki buku-buku kuno yang diwariskan kepada cucunya, Bendara Pangeran Harya Suryamataram, atau yang lebih dikenal dengan Ki Ageng Surya Mataram. Beberap buku tersebut antara lain, Serat Cemporet, Babad Pugeran, Giyanti, Kitab Tadjussalatin, Kitab Ambiya, Serat Maha Bharata, Pustaka Raja Purwa, Pustaka Raja Jarwa, Serat Asmara Supi, Serat Menak, dan Serat Menak Rengganis. Selain itu, keterangan tentang Pangeran Harya Tjakraningrat juga terdapat dalam kitabkitab primbon lain, seperti Kitab Primbon Lukmanakim Adammakna, Primbon Bektijammal Adammakna, dan Primbon Betaljemur Adammakna. (Tjakraningrat 1983, 9).

Penulisan Kitab Primbon Atassadhur Adammakna oleh Pangeran Tjakraningrat bertujuan untuk menjaga wibawa raja dan kerajaan. Primbon tersebut sebenarnya bukan buah pemikiran Pangeran Tjakraningrat, tetapi reproduksi dari pemikiran atau ajaran-ajaran luhur Sri Sultan Hamengku Bowono V. Pada masa ini penyaduran, penulisan, atau penyalinan naskah tergolong banyak, mencapai ratusan. Puncaknya pada tahun 1846-1855 (Riyadi 2002, 37). Tercatat ada sekitar 121 naskah (Behrend 1993, 416). Naskah-naskah tersebut sampai sekarang tersimpan di Museum Widya Budaya Keraton Yogyakarta.

Kitab Primbon Atassadhur Adammakna termasuk Kepustakaan Islam Kejawen yang memuat berbagai macam ilmu gaib yang diyakini sebagai warisan para wali dan leluhur orang Jawa. Sebagaimana dijelaskan dalam purwaka (kata pengantar) Kitab Primbon Atassadhur Adammakna, yang memuat ajaran ilmu kebatinan, ilmu hakekat (ilmu sejati), tata cara Yoga atau Samadi, laku spiritual untuk menggapai ketenangan dan daya linuwih, serta berbagai macam doa dan mantra. Atassadhur Adammakna diyakini memuat berbagai macam ajaran para wali tanah Jawa tentang ilmu kasampurnan (hakikat) yang bersumber dari kitab tasawuf (Noeradya 2008, 14). Atas dasar inilah, tulisan ini berusaha untuk menguraikan bagaimanakah konsep manusia, Tuhan, dan alam dalam Kitab Primbon Atassadhur Adammakna. 


\section{Konsep tentang Tuhan}

Tuhan, dalam Kamus Besar Bahasa Indonesia $(1989,965)$ diartikan sebagai sesuatu yang diyakini, dipuja, disembah oleh manusia sebagai yang Maha Kuasa, Maha Perkasa, dan sebagainya. Orang Islam Kejawen biasa menyebut Tuhan dengan istilah Gusti Allah, dua kata yang merupakan perpaduan antara Jawa (gusti) dan Islam (Allah). Kata gusti, dalam kamus Jawa Kuna memiliki arti tuan atau yang berkuasa dan kelompok khusus dalam masyarakat keraton (Zoetmulder dan Robson 2004, 323). Kata Allah merupakan nama Tuhan dalam bahasa Arab, zat yang Maha Sempurna yang menciptakan alam semesta, Tuhan yang Maha Esa, yang disembah oleh orang-orang yang beriman (KBBI 1989, 23).

Orang Islam Kejawen meyakini adanya asal mula kehidupan ini. Dari mana dia datang, dan akan ke mana setelah hidup, atau yang dikenal dengan istilah sangkan paraning dumadi. Mengenal Tuhan dan mencari jalan untuk bisa menyatu dengan-Nya merupakan dambaan setiap penganut Islam Kejawen. Gambaran Tuhan susah didefinisikan secara riil, demikian juga kenikmatan atau perasaan dekat dengan-Nya. Oleh sebab itu orang Islam Kejawen sering menggunakan tamsil atau perumpamaan. Keberadaan Tuhan bagi kalangan Islam Kejawen sering diistilahkan dengan "cedak tan senggolan, adoh tanpo wangenan" (dekat tapi tidak tersentuh, jauh tapi tidak ada jarak pemisah).

Selain itu, orang kejawen sering memanfaatkan fenomena kehidupan di sekelilingnya untuk mengekspresikan kepercayaan terhadap Tuhan, seperti penyebutan Tuhan dengan istilah "Pangeran". Kata pangeran yang biasanya digunakan untuk memanggil anak raja atau kaum bangsawan, digunakan juga sebagai sebutan bagi Tuhan. Kata pangeran secara keratabasa berasal dari kata pa + ngenger + an. Kata ngenger berarti nderek, ngawula, mengabdi atau melayani tuannya. Dengan demikian pangeran berarti tempat mengabdi dan menghamba warga atau masyarakat di lingkungan istana atau keraton.

Sebutan Pangeran untuk menyebut Tuhan ini sebagaimana diungkapkan dalam Kitab Primbon Atassadhur Adammakna (Noeradya 2008, 14), "Ing sabener-benere manungsa iku kanyatahaning Pangeran, lan Pangeran iku mung sawiji" (pada hakekatnya manusia itu merupakan wujud kenyataan Tuhan, dan Tuhan itu hanya satu). Selain sebutan Pangeran, banyak juga istilah-istilah masa pra-Islam yang digunakan untuk menyebut Tuhan. Kata Sang Hyang, yang berarti Tuhan sering dirangkai dengan sifat-Nya. Seperti, Sang Hyang Wenang berarti Tuhan yang Maha Kuasa; Sang Hyang Guru berarti Tuhan yang memberi ilmu; Sang Hyang Suksma berarti Tuhan yang Maha Lembut; Hyang Jagad Wasesa berarti Tuhan yang Menguasai alam semesta, dan lain sebagainya.

Tuhan dalam Kejawen tidak menciptakan, tetapi emanensi dengan jalan memancar. Menurut Serat Jatimurti, keberadaan ciptaan bukanlah keberadaan yang dapat berdiri sendiri. Keberadaannya bergantung pada keberadaan Tuhan, Sang Pencipta, sedangkan alam atau 
ciptaan ini merupakan manifestasi dari wujud Tuhan sendiri. Konsep pancaran Tuhan inilah yang kemudian menumbuhkan adanya kepercayaan bahwa Tuhan adalah Kang Murbeng Tuwuh, artinya menguasai seluruh kehidupan. Makhluk sebagai wujud keberadaan Tuhan ini sepenuhnya bergantung pada Kang Murbeng Tuwuh (Endraswara 2003, 172).

Suluk Saloka Jiwa karya R. Ng. Ronggowarsito menceritakan bahwa Allah SWT. adalah wujud awal yang sudah ada sebelum segala sesuatu itu ada. Ciptaan Allah SWT. yang pertama kali adalah an-Nur, yang kemudian terpancarlah unsur tanah, api, udara, dan air. Elemen tanah ini kemudian digunakan untuk menciptakan jasad yang terdiri dari darah, daging, dan tulang-tulang (termasuk tulang rusuk). Elemen api melahirkan empat macam jenis jiwa, yaitu: lawwamah, ammarah, nafs shufiyyah, dan muthma'innah. Lawwamah memancarkan sinar hitam, ammarah memancarkan sinar merah, nafs shufyah memancarkan sinar kuning, dan muthma'innah memancarkan sinar putih. Elemen udara melahirkan nafas, tanaffus, anfas, dan nufus (Simuh 1988, 53-54).

Tuhan adalah sesuatu yang misterius, yang tidak dapat dikenali secara fisik. Dia ada dan terpancar dalam diri manusia yang hanya dapat dipahami secara rasa (batiniyah). Eksistensi Tuhan hanya dapat dipahami lewat sifat-sifat-Nya, seperti dalam agama Islam mengenal sifat-sifat Allah yang berjumlah 20 (duapuluh). Kitab Primbon Atassadhur Adammakna (Noeradya 2008, 31) menjabarkan hakikat Zat Tuhan sebagai berikut:

“...menggah kakekatipun dating Pengeran ingkang Mahasuci, sarehne binasakaken sakalangkung gaib, tanpa rupa, tanpa warna, asipat dede jaler, dede estri, dede wandu, sarta boten mawi jaman makam, boten arah boten enggen, dinulu boten katingal, dinumuk boten kantenan, punika isbatipun among cipta sasmita dumunung ingkang waskita..." (Noeradya 2008, 31)

Artinya :

“...sebenarnya hakekat Dzat Tuhan yang mahasuci, sedandainya diibaratkan serba gaib, tidak berupa, tidak berwarna, bersifat bukan laki-laki, bukan perempuan, bukan banci, serta tidak memiliki waktu (zaman) dan tempat (maqam), tidak terikat oleh arah dan tempat, dipandang tidak terlihat, dipegang tidak terasa, begitulah isbat (perumpamaan) dari orang-orang yang sudah waskita....." (Noeradya 2008, 31)

Kitab Primbon Atassadhur Adammakna mengajarkan konsep awang-uwung atau sangkan paraning dumadi, menjelaskan tentang hakikat Zat Tuhan yang Maha Suci dan serba gaib (Tjakraningrat 2008, 31), yaitu:

"Ing sadurunge ana apa-apa, kahaning alam kabir lan alam sahir saisine durung pada dumadi kabeh, kang ana dhihin dhewe amung dat kang maha suci, sajatine dat kang mahasuci iku kang asipat hesa, kabasakaken dat mutlak kadim ajaliabadi.Tegese asipat siji, kang mesthi dhihin dhewe rikala ijih awang - uwung, 
salawase kahanan kita yaiku jummeneng pribadi ana ing sajroning nukad gaib. Kang langgeng dumunung ing urip kita, kayaktene yaiku urip kita.Iki tajalining dat kang mahasuci sajati, mulane wajib padha bisaa rumeksa marang urip kita pribadi, marga saka ngati- ati. Gemi nastiti kang dadi sangkaning panguripan, aywa nganti kapiran nora jumeneng ing uripe, pahe kang wus tininah mukmin kas, kareksa ing babasan: nora susah manawa nandhang kamlaratan, nora uwas yen kaluwen, nora maras yen lagi ginanjar lara, nora miris tekaning pati, manawa taksih tinitah kawula ngam, kudu tumindak ihtiyar, kang andadekake kasantosaning urip". (Tjakraningrat 2008, 31)

Artinya :

"ketika belum ada apa-apa, keadaan alam raya dan alam lahir beserta segala isinya belum ada apa-apa, yang ada hanyalah Zat Yang Mahasuci. HakikatZat Yang Mahasuci itu bersifat Esa, ibaratnya adalah Zat Mutlak Qadim Ajali abadi. Artinya bersifat tunggal, yang pasti ada terlebih dahulu ketika masih awanguwung (hampa).Selamanya keadaan diri peribadi kita berada di dalam nukad gaib, yang langgeng berada di dalam hidup kita, sejatinya hidup ini.Inilah tajallinya Zat Tuhan Yang Mahasuci, maka wajib bagi kita untuk bisa menjaga hidup pribadi kita, dengan berhati-hati.Hati-hati dan cermat yang menjadi asal mula kehidupan, jangan sampai dikesampingkan dalam hidup ini. Demikianlah ciri orang mukmin yang sudah khas, dapat diumpamakan:tidak susah ketika ditimpa kemiskinan, tidak kawatir kelaparan, tidak berduka ketika ditimpa sakit, tidak takut akan datangnya kematian. Tetapi bagi orang yang masih awam, harus melakukan ikhtiar yang dapat mendatangkan kebahagiaan dan kesejahteraan hidup". (Tjakraningrat 2008, 31)

Hal yang sama dapat ditemukan dalam Serat Wirid Hidayat Jati karya Ronggowarsito (Simuh 1988, 283), sebagai berikut:

"sejatine ora ana apa-apa, awit duk maksih awang uwung durung ana sawijiwiji, kang ana dhingin iku Ingsun, ora ana Pangeran anging Ingsun, sejatine Dat kang Amaha Suci, anglimputi ing sipating-Sun, anartani ing asmaning-Sun, amratandhani ing apngaling-Sun". (Simuh 1988, 283)

Artinya:

Sesungguhnya tidak ada apa-apa, karena ketika masih kosong belum ada sesuatupun, yang ada lebih dahulu adalah Aku. Tidak ada Tuhan kecuali Aku, Dzat yang Maha Suci, yang meliputi sifat-Ku, menyertai nama-Ku, menandai perbuatan-Ku". (Simuh 1988, 283)

Berdasarkan penjelasan Serat Wirid Hidayat Jati tersebut dapat diuraikan bahwa Tuhan memiliki sifat : 
a. Dhingin (dahulu), dalam ilmu kalam disebut dengan qadim atau azali yang berarti dahulu, Tuhan adalah wujud awal sebelum ada wujud apa-apa.

b. Dzat yang Maha Esa. "Ora ana Pangeran anging Ingsun”, tidak ada Tuhan kecuali hanya Aku. Sifat ini dalam ilmu kalam disebut dengan wahdaniyah.

c. Maha Suci. Kesucian Tuhan meliputi asma, sifat, dan af'al-Nya. "sejatine Dat kang Amaha Suci, anglimputi ing sipating-Sun, anartani ing asmaning-Sun, amratandhani ing apngaling-Sun". Sifat suci Tuhan yang membedakan dari makhluk-Nya, dalam ilmu kalam dikenal dengan mukhalafatu lil hawadits (berbeda dengan segala makhluk).

Serat Wirid Hidayat Jati memberikan penjelasan tentang bagaimana hubungan antara dzat, sifat, asma, dan af'al (perbuatan) Tuhan. Secara simultan dzat Tuhan meliputi sifat-Nya, sifat menyertai asma-Nya, asma menandai af'al-Nya. Hal ini sebagaimana dijelaskan Simuh $(1988,284)$ sebagai berikut :

Dene Dat, anggenipun anyamadi sipat punika, upami kadi madu lawan manisipun, yekti boten kenging yen kapisahena. Dene sipat anggenipun amartani asma punika, upami kadi surya lawan sorotipun, yekti boten kenging yen kabedakena. Dene asma anggenipun amratandani apngal punika, upami kadi paesan ingkang angilo lawan wawayanganipun, yekti solah-bawanipun ingkang angilo wawayangan wau tumut kemawon".

Artinya :

"Adapun dzat mengandung sifat, seumpama madu dengan rasa manisnya, pasti tidak dapat dipisahkan. Sifat menyertai asma, seumpama matahari dengan sinarnya, pasti tidak dapat dibedakan. Asma menandai perbuatan, seumpama cermin, orang yang bercermin dengan bayangannya, bayangannya pasti akan mengikuti”.

Pangeran Tjakaraningrat maupun Raden Ngabehi Ronggowarsito sebagai seorang pujangga Jawa dengan kecerdasan spiritualnya, memberikan gambaran tentang Tuhan dengan cara metafora (gaya bahasa perbandingan). Langkah ini merupakan langkah akhir setelah akal dan logika buntu mendefinisikan Tuhan. Pendekatan batiniyah merupakan cara terakhir yang dilakukan untuk memahami siapa dan apa Tuhan itu sebenarnya. Tuhan hanya dapat dipahami lewat ngolah rasa (batiniyah) manusia, karena dalam diri manusia terdapat elemen ketuhanan (manusia adalah pancaran Tuhan). Metafora tentang Tuhan dijabarkan dalam Kitab Primbon Atassadhur Adammakna dalam wolung papangkatan (delapan tingkatan). Tingkatan tersebut merupakan proses pengenalan siapa Tuhan yang sebenarnya sampai bagaimana Tuhan menciptakan alam semesta, seperti bumi, langit, matahari, bulan, bintang, api, angin, air, dan juga manusia. 


\section{Konsep tentang Manusia}

Konsep manusia dalam Kejawen tidak dapat dipisahkan dengan konsep ke-Tuhan-an. Manusia sebagai pancaran Tuhan disebut sebagai jagad cilik (micro cosmos), sedangkan alam semesta ini disebut dengan jagad gedhe (macro cosmos). Manusia merupakan makhluk Tuhan yang paling sempurna, karena memiliki unsur-unsur ketuhanan. Oleh sebab itu manusia berupaya untuk menemukan jalan untuk kembali kepada asal muasalnya, menemukan jati dirinya, dan akan ke mana ia setelah mati (sangkan paraning dumadi). Konsep inilah yang melandasi orang kejawen untuk melakukan olah rasa, berusaha menemukan keselamatan dan kebahagiaan hidup yang abadi.

Manusia dalam pandangan kejawen dianggap sebagai carangan Tuhan, penjelmaan Tuhan secara mistis. Proses penciptaan manusia dalam konsep Islam Kejawen melalui 7 (tujuh) tahapan, sebagaimana diuraikan dalam Kitab Primbon Atassadhur Adammakna (Noeradya 2008, 15) sebagai berikut:

a. Alam awang-uwung. Ruang kosong yang belum ada apa-apa, ruang yang tanpa permulaan dan tanpa penghabisan, yaitu alam Ilahiah yang sangat rahasia.

b. Cahaya, "Ingsun anganakake cahya minangka panuksmaningsun dumunung ana ing alam pasenedaningsun". Cahaya merupakan tempat singgahnya suksma dari Tuhan.

c. Wawayangan (gambaran), Ingsun anganakake wawayangan, minangka panuksma lan dadi rahsaningsun, dumunung ana ing alam pambabaring wiji. Wawayangan merupakan design atau bentuk abstrak tempat bersemayamnya suksma dan rasa yang berada di alam pambabaring wiji (penanaman biji).

d. Suksma. Ingsung anganakake suksma, minangka dadi pratandha kauripaningsun, dumunung ana alaming getih. Suksma merupakan tanda-tanda kehidupan yang terletak pada dalam darah.

e. Angen-angen. Ingsun anganakake angen-angen kang uga dadi warna-ningsun, ana ing dalem alam kang lagi kena kaumpamaake bae. Angen-angen merupakan tanda-tanda keberadaan Tuhan yang berada di alam yang sudah dapat dijangkau manusia.

f. Budi. Ingsung anganakake budi, kang minangka kanyatahan pencaring angen-angen kang dumunung ana ing dalem alaming badan alus. Budi merupakan menyebarnya wujud angen-angen yang berada di alam badan halus.

g. Sajatining manungsa. Ingsung anggelar warana kang minangka kakandhangan sakabehing paserenaningsun. Kasebut nem perkara ing duwur mau tumitah ana ing donya iya iku sajatining manungsa. Tuhan menunjukkan eksistensi-Nya dalam warana (media) yang berwujud manusia sejati yang berada di alam dunia ini, yang terbentuk melalui enam proses tersebut. 
Berdasarkan uraian tersebut, terlihat proses penciptaan manusia melalui pancaran (tajalli) dzat Tuhan sebanyak tujuh tingkatan sampai menjadi wujud manusia. Tingkatan tersebut yaitu: Alam Awang uwung, Cahaya, Wawayangan, Suksma, Angen-angen, Budi, dan Manusia Sejati. Ajaran tajalliat tersebut merupakan paham wahdat al wujud yang lebih sesuai dengan kepercayaan masyarakat Jawa (Shihab 2009, 237).

\section{Konsep tentang Alam}

Jagad gedhe dan jagad cilik merupakan satu kesatuan sebagai bentuk manifestasi Tuhan. Alam, Tuhan, dan manusia merupakan satu kesatuan pemahaman dalam konsep Kejawen. Islam Kejawen meyakini, bahwa alam semesta yang menjadi kehidupan nyata manusia bermula dari dzat Allah (Simuh 1988, 334).

Kepercayaan orang kejawen terhadap alam secara, umum dibedakan menjadi tiga, yaitu: alam purwa, alam madya, dan alam wasana. Trikotomi alam hidup manusia ini merupakan satu kesatuan yang tidak dapat dipisahkan, siklus kehidupan yang dikenal dengan Cakra Manggilingan (Endraswara 2003, 190). Pembagian alam ini sesuai dengan konsep pembagian waktu, yaitu: masa lampau (past), sekarang (present), dan masa akan datang (future).

Alam purwa merupakan alam sonya ruri atau alam awang-uwung yang masih kosong belum wujud apa-apa. Alam madya adalah alam dunia, di mana manusia menjalani hidup nyata, sebagai represantasi hidupnya ketika masih di alam purwa, dan sebagai bekal kelak menjalani hidup di alam wasana. Alam Wasana adalah alam terakhir dari kehidupan manusia, atau biasa disebut dengan alam kalanggengan (abadi).

Kitab Primbon Atassadhur Adammakna menjabarkan tentang alam sebagai berikut (Noeradya 2008, 54-57):

a. Alam Rokhiyah. Alam ini merupakan alamnya nyawa, terangnya melebihi cahaya di siang hari, tidak ada arah Timur, Utara, Selatan, Barat, Tengah, Bawah maupun Atas.

b. Alam Siriyah. Alam ini merupakan bersemayamnya rasa, terangnya melebihi alam Rokhiyah. Di alam Siriyah ini terdapat empat macam cahaya, yaitu: hitam, merah, kuning, dan putih. Keempat cahaya tersebut merupakan tempatnya budi, yang menjadikan wahana bagi hawa nafsu. Warna hitam melahirkan nafsu Aluamah, warna merah melahirkan nafsu Amarah, warna kuning melahirkan nafsu Supiyah, warna putih melahirkan nafsu Mutmainnah.

c. Alam Nuriyah, maksudnya adalah alam cahaya yang terangnya melebihi alam Siriyah. Di alam ini terpancar cahaya aneka warna: hitam, merah, kuning, putih, hijau, semua tampak indah dan menjadi wahana bagi Pancadriya (panca indera) yang ditambah dengan cahaya Pramana (pengetahuan). 
d. Alam Uluhiyah. Alam ini merupakan alam ketuhanan (Ilahiah) yang terangnya melebihi alam Nuriyah. Di alam Uluhiyah ini terpancar cahaya yang di dalamnya terlihat seperti lebah menggantung, berada di maqam fana, maksudnya tempat waskita, yaitu sukma.

Konsep tentang alam juga dijelaskan dalam Serat Wirid Hidayat Jati, bahwa alam dibagi menjadi dua, yaitu alam batin dan alam lahir (Simuh 1988, 320-321). Alam batin terdiri dari :

a. Martabat Ahadiyah, yaitu martabat la tayun dan ithlaq. Artinya masih dalam wujud mutlak, tidak dapat dikenal hakikatnya.

b. Martabat Ta'yun Awal (awal kenyataan). Martabat ini disebut Wahdat dan Hakikat Kemuhammadan (Nur Muhammad). Pada martabat ini belum ada pemisahan, segala perwujudan masih bersifat global atau mujmal.

c. Martabat Ta'yun Kedua atau Wahidiyat. Martabat ini sudah terdapat pemisahan yang maujud, tetapi masih dalam bentuk kesatuan yang mengandung kejamakan.

Ketiga martabat tersebut bersifat batin dan Ilahi, sesuai dengan sifat Ilahiah sendiri yang qadim dan azali. Dari ketiga martabat ini terpancarlah alam atau martabat lahir. Adapun alam lahir terdiri dari : (1) Martabat alam arwah. Pada martabat ini berupa "Nur Muhammad" yang diciptakan oleh Allah Swt dari nur-Nya, dan dari nur Muhammad inilah yang kemudian menjadi ruh segala makhluk atau ciptaan. (2) Martabat alam mitsal, martabat ini merupakan diferensiasi dari Nur Muhammad ke dalam ruh individual setiap makhluk. (3) Martabat alam ajsam, martabat ini berupa alam material yang terdiri dari empat unsur, yaitu api, angin, tanah, dan air. Keempat anasir atau elemen tersebut yang kemudian menjelma menjadi wujud lahiriah, dan keempat anasir tersebut saling merupakan satu kesatuan yang tidak terpisah. (4) Martabat insan kamil atau alam paripurna. Martabat ini merupakan bentuk atau wujud paripurna dari semua martabat sebelumnya, yang berupa manusia "Insan Kamil”.

Dalam konsep Jawa, insan kamil (manusia sempurna) tidak hanya Nabi Muhammad SAW saja, tetapi setiap manusia dapat menjadi insan kamil. Nabi Muhammad SAW. sebagai insan kamil, tidak hanya sekedar dipahami dari segi lahiriah (syariat), tetapi harus dipahami dari segi ruhaniah atau hakekatnya. Pada hakekatnya Nabi Muhammad SAW adalah manusia yang memiliki sifat, zat, dan af'al yang mampu manunggal dengan Allah SWT (Khalim 2010, 81). Badan manusia merupakan cerminan dzat Tuhan, tempatnya rasa yang berasal dari ruh idhafi, ruh Muhammad Rasul, yaitu dari rasa hidup (Hariwijaya 2004, 156).

Berdasarkan konsep manusia pada hakekatnya dapat menjadi insan kamil inilah yang kemudian mengilhami berbagai laku ritual atau spiritual untuk meraih derajat ruhaniah tertinggi, jumbuh atau manunggal dengan Tuhan. Bagi orang kejawen, menjaga keselarasan hubungan antara manusia dengan alam adalah kewajiban sesuai dengan falsafah "memayu hayuning bawana" (menjaga keseimbangan alam). Keselarasan hubungan manusia dengan alam fisik dan alam ruhani (semua makhluk gaib termasuk Tuhan), merupakan hal pokok 
untuk mendapat keselamatan di dunia dan akhirat. Selain itu juga harus ditunjang dengan kerukunan dan rasa hormat terhadap sesama dalam kehidupan sosial. Ajaran menjaga keselarasan dengan berdasarkan etika rasa rukun dan hormat inilah yang disebut Frans Magniz Suseno, sebagai etika Jawa (Suseno 1984, 38). Konsep menjaga keselarasan untuk mendapat keselamatan ini yang kemudian memunculkan berbagai macam adat, tradisi, dan ritual yang kemudian dikenal dengan istilah "selametan".

Ritual selamatan berupa upacara makan bersama. Adapun makanan yang disajikan berupa menu tertentu yang telah diberi doa oleh seorang modin, kemudian dibagi-bagikan kepada orang-orang di sekelilingnya. Selametan sangat berkaitan dengan kepercayaan kepada alam adikodrati, unsur-unsur kekuatan sakti atau makhluk halus. Selametan merupakan media untuk menjaga keharmonisan hubungan antara manusia dengan alam sekitarnya, agar memperoleh keselamatan hidup dan terhindar dari marabahaya.

Upacara atau tradisi selametan ini kemudian digunakan dalam berbagai aktifitas kehidupan sosial orang Jawa, seperti mendirikan atau pindah rumah, pernikahan, melahirkan, khitanan, bahkan sampai pada selamatan untuk orang meninggal. Dengan demikian slametan merupakan ritual penting dalam tradisi Jawa (Syam 2013, 3).

Ritual selamatan (selametan) dalam masyarakat Jawa terkait dengan peristiwa dan kejadian sehari-hari yang dialami. Menurut Koentjaraningrat $(1984,346)$ ritual selamatan dapat digolongkan menjadi 4 (empat) macam, yaitu:

a. Terkait dengan siklus hidup manusia (life cycle), seperti hamil tujuh bulan, kelahiran, upacara potong rambut pertama, upacara tedhak siten (bayi menyentuh tanah untuk pertama kali), upacara menusuk telinga, sunatan, kematian, dan setelah kematian.

b. Terkaitan dengan lingkungan, seperti bersih desa, penggarapan tanah pertanian, dan setelah panen padi.

c. Berhubungan dengan hari-hari serta bulan-bulan besar Islam.

d. Bersifat insidental (berkaitan dengan peristiwa-peristiwa tertentu), seperti akan mengadakan perjalanan jauh, menempati rumah baru, menolak bahaya (tolak balak), kaul (janji kalau sembuh dari sakit), dan lain-lain.

Keempat jenis selametan tersebut tidak dapat dipisahkan antara satu dengan yang lainnya. Ini merupakan upaya membangun harmoni antara manusia, Tuhan, dan alam (memayu hayuning bawana). Keselarasan antara alam fisik dan alam ruhaniah sebagai jalan untuk mendapatkan keselamatan di dunia dan akhirat. Dengan demikian, konsep selametan bagi orang Islam kejawen memiliki nilai teologis dan sosiologis. Secara teologis, menciptakan hubungan harmonis dengan Tuhan, sedangkan secara sosiologis menjaga hubungan harmoni dengan sesama manusia dan alam lingkungan. 


\section{Kesimpulan}

Kitab Primbon Atassadhur Adammakna sebagai kepustakaan Islam Kejawen memberikan banyak pengetahuan tentang manusia, Tuhan, dan alam. Kitab primbon ini merupakan salah satu bentuk ekspresi keberagamaan masyarakat Jawa, khususnya lingkungan keraton. Mengadopsi ajaran Islam, khususnya ilmu tasawuf untuk mendakwahkan islam di lingkungan istana. Ajaran tentang Tuhan, manusia, dan alam dijabarkan sesuai dengan adat dan budaya yang melingkupinya. Hubungan manusia, Tuhan, dan alam diuraikan secara kejawaan, sebagai satu kesatuan yang tidak dapat dipisahkan.

Bagi orang Jawa, menjaga keselarasan hubungan antara manusia dengan alam adalah kewajiban "memayu hayuning bawana". Menjaga keharmonisan hubungan dengan alam sama artinya menjaga keharmonisan dengan Tuhan, sebagai Sang Pencipta Semesta. Dengan demikian keselarasan hubungan manusia dengan alam fisik dan alam ruhani (semua makhluk gaib termasuk Tuhan), menjadi jalan untuk Jumbuh atau manunggal, mendapat kebahagiaan dan keselamatan di dunia dan akhirat.

\section{Referensi}

Alfian, Teuku Ibrahim, 1998, “Tajussalatin Versi Kraton Yogyakarta” dalam Islam dan Khazanah Budaya Kraton Yogyakarta, Yogyakarta: Yayasan Kebudayaan Islam Indonesia.

Amin, Darori, 2011, Konsepsi Manunggaling Kawula Gusti Dalam Kepustakaan Islam Kejawen (Studi Analisis Suluk Sujinah),Jakarta: Badan Litbang dan Diklat Kementerian Agama RI.

Ardani, Moh, 1995, Al Qur'an dan Sufisme Mangkunegara IV (Studi Serat-serat Piwulang), Jakarta : PT Dana Bhakti Wakaf.

Azra, Azyumardi, 1994, Jaringan Ulama Timur Tengah dan Kepulauan Nusantara Abad XVII dan XVIII: Akar Pembaruan Islam Indonesia, Bandung: Mizan.

Behrend, T.E. 1993. "Manuscript Production in Nineteenth-Century Java" dalam Bijdragen Tot de Taal, Land-en Volkenkunde. Deel 149. Leiden.

Bleicher, Josef, 2003, Hermeneutika Kontemporer: Hermeneutika Sebagai Metode, Filsafat, dan Kritik, diterjemahkan dari Contemporary Hermeneutic oleh Ahmad Norma Permata, Yogyakarta: Fajar Pustaka Baru.

Boechari, Sidi Ibrahim, 1971, Sedjarah Masuknja Islam dan Proses Islamisasi di Indonesia, Jakarat: Publicita

Damami, Mohammad , 2000, Tasawuf Positif dalam Pemikiran HAMKA, Yogyakarta: Fajar Pustaka Baru. 
Departemen Agama Republik Indonesia, 1989, Al-Quran dan Terjemahnya, Bandung: Lubuk Agung

Djamil, Abdul, 1999, Aspek Islam Dalam Sastra Mistik, Dewaruci: Jurnal Dinamika Islam dan Budaya Jawa, No. 1. IAIN Walisongo Semarang. ,2001, Perlawanan Kiai Desa: Pemikiran dan Gerakan Islam KH. Ahmad Rifa’i Kalisalak, Yogyakarta: LKiS.

Dwiyanto, Djoko, 2009, Kraton Yogyakarta: Sejarah, Nasionalisme, dan Teladan Perjuangan, Yogyakarta: Paradigma Indonesia.

Endraswara, Suwardi, 2003, Mistik Kejawen: Sinkritisme, Simbolisme dan Sufisme dalam Budaya Spiritual Jawa, Yogyakarta: Narasi.

, 2011, Kebatinan Jawa dan Jagad Mistik Kejawen, Yogyakarta: Lembu Jawa.

Geertz, Clifford, 2014, Agama Jawa: Abangan, Santri, Priyayi dalam Kebudayaan Jawa, diterjemahkan oleh Aswab Mahasin dan Bur Rasuanto, dari The Religion of Java, Jakarta: Komunitas Bambu.

Hadikusuma, Hilman, 1993, Antropologi Agama, Bandung: Citra Aditya Bakti.

Hariwijaya, M., 2004, Islam Kejawen, Yogyakarta: Gelombang Pasang.

Kartohasmoro, 2008, Kitab Primbon Ajimantrawara, Yogabrata, Rajah Yoga Mantra. Capcapan Kaping 30, Yogyakarta: Soemodidjoyo Mahadewa dan CV. Buana Raya.

Khalim, Samidi, 2008, Islam dan Spiritualitas Jawa, Semarang: Primamedia Press. ,2010, Salat Islam Kejawen, Semarang: Primamedia Press.

Koentaraningrat, 1984, Kebudayaan Jawa, Jakarta: Balai Pustaka.

Muljana, Slamet, 2008, Runtuhnya Kerajaan Hindu-Jawa dan Timbulnya Negara-negara Islam di Nusantara, Cetakan III, Yogyakarta: LKiS.

Mulder, Niels, 1984, Kebatinan dan Hidup Sehari-hari Orang Jawa: Kelangsungan dan Perubahan Kulturil, cetakan kedua, Jakarta: Gramedia.

Tjakraningrat, 2013, Kitab Primbon Betaljemur Adammakna, Cap-capan Kaping 58, Yogyakarta: Soemodidjoyo Mahadewa dan CV. Buana Raya. , 1983, Kitab Primbon Bektijamal Adammakna, Yogyakarta: Soemodidjoyo Mahadewa dan CV. Buana Raya. ,2008a, Kitab Primbon Atassadhur Adammakna, Yogyakarta: Soemodidjoyo Mahadewa dan CV. Buana Raya. ,2008b, Kitab Primbon Ajimantrawara, Yogabrata, Rajah Yoga Mantra. Capcapan Kaping 30, Yogyakarta: Soemodidjoyo Mahadewa dan CV. Buana Raya. 2013, Kitab Primbon Betaljemur Adammakna, Cap-capan Kaping 58, Yogyakarta: Soemodidjoyo Mahadewa dan CV. Buana Raya. 
Partini, 2010, Serat Sastra Gending Warisan Spiritual Sultan Agung yang Berguna untuk Memandu Olah Pikir dan Olah Dzikir, Yogyakarta: Panji Pustaka.

Riyadi, Slamet, 2002, Tradisi Kehidupan Sastra di Kasultanan Yogyakarta, Yogyakarta: Gama Media.

Santosa, Iman Budi, 2012, Spiritualisme Jawa: Sejarah, Laku, dan Intisari Ajaran, Yogyakarta: Memayu Publishing.

Shihab, Alwi, 2009, Antara Tasawuf Sunni dan Tasawuf Falsafi: Akar Tasawuf di Indonesia. Jakarta: Pustaka Iman.

Simuh, 1988, Mistik Islam Kejawen R.Ng. Ronggowarsito, Jakarta: UI Press. ,2000, Sufisme Jawa, Yogyakarta: Bentang Budaya.

Soeratman, Darsiti, 1990, Kehidupan Dunia Kraton Surakarta 1830-1939, Yogyakarta: Disertasi Pascasarjana UGM.

Suseno, Frans Magniz, 1985, Etika Jawa Sebuah Analisis Falsafi tentang Kebijaksanaan Orang Jawa, Jakarta: Gramedia. 